\title{
Do managers use earnings guidance to influence street earnings exclusions?
}

\author{
Theodore E. Christensen • Kenneth J. Merkley • \\ Jennifer Wu Tucker $\cdot$ Shankar Venkataraman
}

Published online: 31 May 2011

(C) Springer Science+Business Media, LLC 2011

\begin{abstract}
Despite the apparent importance of "street earnings" to investors, we know relatively little about the process through which this earnings metric is determined. The limited evidence in the extant literature provides analyst-centric explanations, suggesting that analysts' abilities and incentives influence which line items forecast-tracking services exclude from GAAP earnings to arrive at street earnings. We propose an alternative explanation: managers actively influence analysts' forecast exclusion decisions via earnings guidance. We test this explanation by examining how earnings guidance influences two aspects of analysts' exclusions: (1) special item exclusions (i.e., nonrecurring items) and (2) incremental exclusions (i.e., recurring items). We find that for firms with no special items in the previous year, when managers guide, analysts exclude almost all current-year special items, whereas when managers do not guide, the proportion that analysts exclude is significantly lower. More importantly, we that analysts' incremental exclusions are significantly higher when managers guide than when they do not
\end{abstract}

Data availability The data are available from the public sources identified in the text.

T. E. Christensen ( $₫)$

Marriott School of Management, Brigham Young University, Provo, UT, USA

e-mail: ted_christensen@byu.edu

K. J. Merkley

Johnson Graduate School of Management, Cornell University, Ithaca, NY, USA

e-mail: kjm267@cornell.edu

J. W. Tucker

Fisher School of Accounting, University of Florida, Gainesville, FL, US

e-mail: jenny.tucker@warrington.ufl.edu

S. Venkataraman

College of Management, Georgia Institute of Technology, Atlanta, GA, USA

e-mail: shankar.venkataraman@mgt.gatech.edu 
guide. Overall, our evidence suggests that managers play an active role in influencing the composition of street earnings via earnings guidance.

Keywords Street earnings - Earnings guidance - Special items · Pro forma guidance

\section{JEL Classification M40}

\section{Introduction}

We investigate whether managers use earnings guidance as a tool to influence the composition of street earnings. Analyst forecast tracking services, such as $\mathrm{I} / \mathrm{B} / \mathrm{E} / \mathrm{S}$ and First Call, exclude certain earnings components in calculating a firm's "core earnings" and this core earnings measure is often referred to as "street earnings." Prior research suggests that (1) investors react more to street earnings than to GAAP earnings and (2) investors extrapolate current performance into sustainable future earnings, making street earnings more relevant for equity valuation than other versions of core earnings (Bradshaw and Sloan 2002; Brown and Sivakumar 2003; Frankel and Roychowdhury 2005). Despite the apparent importance of street earnings to investors, the process by which the composition of street earnings is determined is poorly understood. Prior research provides analyst-centric explanations, such as analyst ability (Gu and Chen 2004) and analyst incentives (Baik et al. 2009), for the exclusion of certain earnings components from street earnings. We explore an alternative (though not mutually exclusive) explanation: managers actively influence analysts' exclusion decisions via earnings guidance. ${ }^{2}$

The communication between managers and analysts is an important determinant of market expectations for future earnings. Prior research finds that managers are able to "walk down" analysts' earnings estimates through earnings guidance during the accounting period when managers consider analysts' forecasts to be overly optimistic (Matsumoto 2002; Cotter et al. 2006; Richardson et al. 2004). In addition to directly guiding the level of earnings expectations to influence the sign and level of earnings surprises, managers may also use earnings guidance to influence the composition of analyst earnings forecasts and therefore influence street earnings reported at the end of the period. This can be the case because forecast tracking services rely on the earnings components forecasted by the majority of analysts during the fiscal period to determine the exclusions from their street earnings number at the end of the period. ${ }^{3}$

\footnotetext{
${ }^{1}$ Some studies have used the terms "pro forma earnings" and "street earnings" interchangeably (e.g., Bradshaw and Sloan 2002). We use the term "street earnings" to refer to the non-GAAP realized earnings numbers reported by analyst forecast tracking services and "pro forma earnings" to refer to the nonGAAP realized earnings disclosed by managers (e.g., Gu and Chen 2004; Bhattacharya et al. 2007).

2 Although analysts occasionally include certain nonrecurring income items, for brevity we use the term "exclusion" to refer to both expense (loss) exclusions and income (gain) inclusions.

3 First Call notes: "The estimates have been adjusted to exclude any unusual items that a majority of the contributing analysts deem non-operating and/or nonrecurring" and "The values in the Actuals table have
} 
To illustrate how managers can influence analysts' forecast exclusions, consider the earnings guidance issued by Amazon and eBay in 2009. ${ }^{4}$ Both firms are (1) high-tech companies, (2) members of the S\&P 500, (3) classified in the same 2-digit SIC code, and (4) widely followed by analysts. Both companies estimated two significant expense items - the amortization of intangibles and stock-based compensation. Amazon provided a GAAP forecast that included both items in its earnings estimate. eBay, on the other hand, provided both GAAP guidance and pro forma guidance-forecasts in which managers explicitly exclude certain earnings components from the earnings estimate-and made the case in its pro forma guidance that amortization of intangibles and stock compensation expense do not reflect results from ongoing operations and therefore should be excluded in determining core earnings. ${ }^{5}$ Strikingly, analysts' consensus earnings estimates during the period and the ex post street earnings numbers included both items for Amazon but excluded both items for eBay. ${ }^{6}$ This evidence, albeit anecdotal, suggests that analysts' street earnings exclusion decisions vary from firm to firm and that managers may be able to influence these decisions.

Total exclusions from street earnings - that is, the difference between street earnings and GAAP earnings_-are composed of (1) special item exclusions (i.e., nonrecurring items) and (2) incremental exclusions (i.e., recurring items). Special items are defined as "one-time" items and include asset write-downs and write-offs, gains or losses from asset sales and early retirement of debts, legal settlements, restructuring charges, etc. In concept, since special items are by definition transitory, their exclusion is justified because they are difficult to predict and are not useful in predicting future earnings. In practice, however, special items frequently include items that are not necessarily "one-time" or purely transitory (McVay 2006). Moreover, the economic events that trigger the recognition of special items are often associated with firm-specific uncertainty such that analysts might be unsure about the duration and magnitude of the effects of such events (Elliott and Hanna 1996). Thus, analysts do not always exclude all special items from their forecasts (Bradshaw and Sloan 2002, p. 60). It is likely that analysts may find managers' earnings guidance helpful in assessing the persistence of specific line items included in special items. Accordingly, we predict that analysts are more likely to exclude the appropriate (or at least defensible) amount of special items when managers guide than when they do not guide.

"Incremental exclusions," on the other hand, are analysts' exclusions of line items beyond special items. Incremental exclusions represent the less-justifiable

\section{Footnote 3 continued}

been adjusted to exclude any unusual items that a majority of the contributing analysts deem nonoperating and/or nonrecurring" (First Call Historical Database User Guide, pp. 8-9).

4 See Amazon's press release on Oct. 22, 2009 and eBay's press release on Oct. 21, 2009.

5 Regulation G requires the reconciliation of pro forma earnings and GAAP earnings, but is silent about whether pro forma guidance needs to be reconciled with GAAP earnings guidance. Some firms provide both GAAP and pro forma guidance either for informative or opportunistic reasons.

${ }^{6}$ We infer this information from the actual analysts' consensus estimate available from a Thomson Reuters research report for each company. Market Watch (October 21, 2009) provides additional confirmation. 
component of analysts' total exclusions because they are generally recurring items, such as research and development expense, depreciation and amortization, stockbased compensation, and interest- or tax-related items. For example, Doyle et al. (2003) report that incremental exclusions are almost as predictive of future cash flows as the street earnings number itself, suggesting that incremental exclusions are essentially composed of recurring items. Because of the recurring nature of these items, analysts are unlikely to exclude them from their forecasts absent management intervention. However, since managers presumably understand their business and the nature of their income statement line items better than outsiders, analysts are likely to seriously consider guidance from managers during the fiscal period about the exclusion of these items even though they are not traditionally defined as special items. Therefore, we predict that analysts are more likely to make incremental exclusions when managers guide than when they do not guide. Evidence consistent with this prediction is particularly important because it would provide more compelling evidence of managers' active influence in the composition of street earnings since special items are determined more objectively.

In our empirical tests, we assume that Compustat's "special items" variable represents an objective measure of transitory items because (1) Compustat has no known incentive to bias the amount and (2) Compustat actively searches both reported line items on the income statement and disclosed information in the accompanying notes to classify these items (Frankel 2009; Burgstahler et al. 2002). We find evidence consistent with our predictions regarding the influence of management earnings guidance on analysts' special-item exclusions and incremental exclusions. In particular, we find that for firms with no special items in the previous year, when managers guide, analysts exclude almost all current-year special items, whereas when managers do not guide, the proportion of special items that analysts exclude is significantly lower. More importantly, we find that analysts' incremental exclusions are significantly higher when managers guide than when they do not guide.

To further understand these results, we hand-collect a subsample of firms and code the type of earnings guidance and the frequency of various types of exclusions explicit in the guidance. We observe that pro forma guidance is prevalent and that many of the exclusions are recurring expenses. In addition, we analyze analysts' exclusion decisions of a specific recurring expense-stock-based compensationand find that earnings guidance is positively associated with analysts' exclusions of this expense. Taken together, our evidence is consistent with the notion that managers influence analysts' street earnings exclusions through earnings guidance.

This study contributes to the street earnings literature by providing insights into the determination of street earnings. Gu and Chen (2004) find that the items analysts include are more persistent than those they exclude, consistent with analysts having expertise in distinguishing persistent from transitory items. Baik et al. (2009) conjecture that analysts have incentives to promote glamour stocks and find that analysts are more likely to exclude expenses for glamour stocks than for value stocks. Both studies focus on how analysts' ability and incentives influence the determination of street earnings. We extend this stream of research by providing 
preliminary evidence that managers also play an active role in determining the composition of street earnings.

The paper proceeds as follows. Section 2 reviews relevant research and develops the hypotheses. Section 3 outlines the research design. Section 4 describes the sample. Section 5 presents the main test results along with robustness tests and Section 6 discusses supplementary analyses. Section 7 concludes.

\section{Background and hypothesis development}

\subsection{Background}

Our research is motivated by a broader interest in how managers communicate with analysts in setting market expectations. The interaction between managers and analysts, either in public or in private, has been well documented in prior research. Much of this research addresses the role of managers' guidance in setting the level of market earnings expectations to produce a desired sign or level of earnings surprise at the earnings announcement date (Ajinkya and Gift 1984; Matsumoto 2002; Hutton 2005; Cotter et al. 2006; Wang 2007). Our research differs from these studies in that our focus is on managers' efforts to manage the components of earnings that analysts include in their earnings estimates and subsequently in street earnings. This effort will not affect the sign (or level) of earnings surprises as long as analyst forecast tracking services consistently exclude certain components in both the estimates and street earnings.

To illustrate the difference in focus, consider two scenarios. One scenario is that a firm manages analysts' earnings expectations by telling analysts that their estimates for depreciation and amortization expenses are too low. Such guidance would result in a downward adjustment in analysts' earnings expectations and a potentially positive earnings surprise at the earnings announcement date. In the other scenario, a manager attempts to manage the core earnings level as perceived by analysts (that is, "street earnings") by telling analysts that they should not include depreciation and amortization expenses in their earnings estimates because these measures are historical-cost-based estimates that do not meaningfully measure the company's current performance. ${ }^{7}$ Guidance of this nature will not affect the short-term earnings surprise but will result in higher street earnings if analysts exclude these expenses. In addition, this guidance could boost the company's stock price if investors extrapolate these earnings into the future. While prior research has focused predominantly on the first scenario, we explore the second.

\footnotetext{
7 For example, see Akamai's earnings guidance press release dated Feb. 4, 2009, where managers describe their rationale for excluding depreciation and amortization expense as follows: "Adjusted EBITDA also excludes depreciation and amortization expense, which is based on the company's estimate of the useful life of tangible and intangible assets. These estimates could vary from actual performance of the asset, are based on historic cost incurred to build out the company's deployed network, and may not be indicative of current or future capital expenditures." Similar justifications are routinely offered by companies seeking to exclude other recurring expenses.
} 


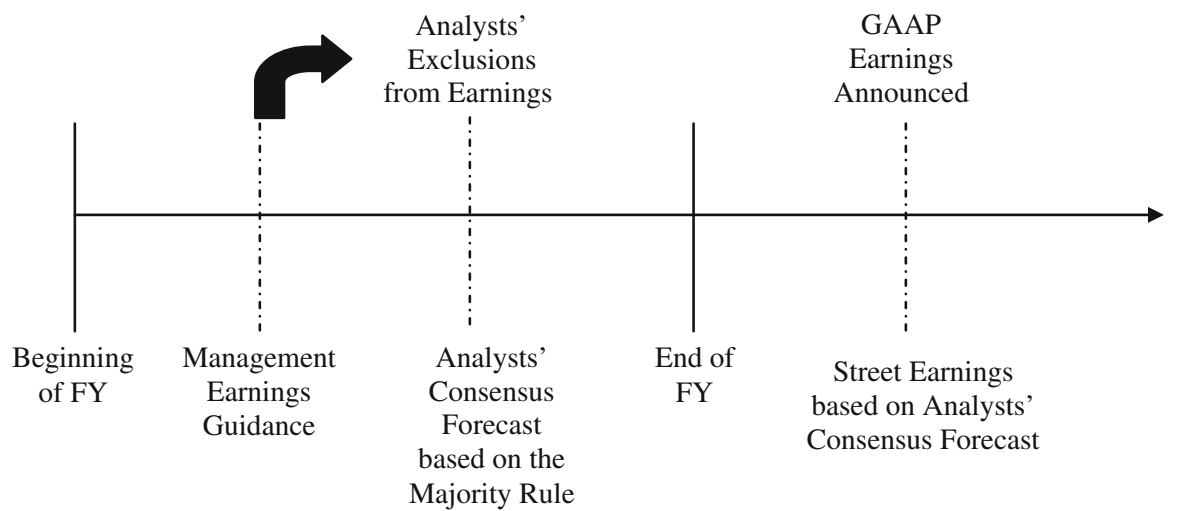

Fig. 1 Time line

Prior research acknowledges - but does not test-the question of whether managers influence the composition of street earnings. Bradshaw and Sloan (2002, p. 47) state that "it is unclear whether an explicit focus on street definitions of earnings originates with managers or analysts." Gu and Chen (2004) conclude that analysts' expertise plays a key role in distinguishing persistent earnings components from transitory components. In a supplementary analysis, they explore whether the emphasis on street earnings begins with managers or analysts. Their test, however, does not allow them to conclusively answer this question. ${ }^{8}$ Observing that analysts' exclusions coincide with manager's pro forma earnings exclusions for $70 \%$ of their UK sample, Choi et al. (2007, p. 605) speculate that such a high level of agreement might have resulted from managers' guidance. While concluding that analysts are more likely to make income-increasing adjustments for glamour stocks than for value stocks, Baik et al. (2009) acknowledge that the adjustments could have been initiated by managers.

We specifically examine the role that managers play, via earnings guidance, in influencing the composition of street earnings. Figure 1 provides a conceptual timeline of the key events involved in determining a firm's street earnings. During the fiscal period, analysts make individual earnings forecasts and decide what earnings components are included in or excluded from their respective forecasts. A forecast-tracking service then aggregates these individual forecasts to form a consensus estimate. After the firm announces realized earnings, the forecasttracking service adjusts GAAP earnings based on the exclusion decisions made by the majority of analysts during the fiscal period to determine street earnings. We investigate whether managers influence this process by providing guidance during the period about the earnings components that analysts should forecast.

\footnotetext{
8 They hand-collect a subsample of pro forma earnings at the earnings announcement to determine where street earnings come from. This timing, however, might be too late, because analyst tracking services use the "majority rule" and by the time of the earnings announcement, all analysts have already made their forecasts. Assuming forecast tracking services consistently follow the majority rule, the announced pro forma earnings would be too late to influence what components should be excluded from street earnings.
} 


\subsection{Hypotheses development}

Prior research finds that street earnings are more value-relevant to investors than GAAP operating earnings (Bradshaw and Sloan 2002). This result is intuitive because street earnings remove the transitory components of earnings (which are not very useful in predicting future earnings) and capture an earnings number that is predictive of future earnings (Francis et al. 1996; Ramakrishnan and Thomas 1998). Unlike GAAP earnings, there are no standard rules about what constitutes "core earnings." Two available measures are analysts' version of core earnings (i.e., street earnings) and Compustat's version of core earnings. ${ }^{9}$ Brown and Sivakumar (2003) find that investors use street earnings in equity valuation to a larger extent than Compustat's version of core earnings, suggesting that street earnings should be the number on which managers focus if they are interested in favorable valuations of their stocks. Analysts appear to exercise substantial discretion in arriving at the street earnings number and their exclusion decisions are often firm-specific (Doyle et al. 2003; Barth et al. 2009). For example, Doyle et al. (2003, p. 148) state, "What gets excluded in a particular firm's definition of pro forma earnings varies greatly across companies, and the variation cuts across line items on the income statement and categories of accruals." Note that they use the term "pro forma earnings" to mean "street earnings." Thus, managers may have a strong incentive to seek higher street earnings by guiding analysts' exclusion decisions.

To influence investors' perceptions of a firm's future performance, managers may also (1) engage in classification shifting (McVay 2006) and (2) present their own pro forma realized earnings in their earnings announcements. If a firm voluntarily discloses a pro forma earnings number at the end of the fiscal year, the components of the pro forma earnings number should be similar to those in any pro forma earnings guidance issued earlier during the fiscal year. Perhaps this is why Bhattacharya et al. (2003) report that, for $65 \%$ of their sample, the street earnings number equals the realized pro forma earnings metric. When the two numbers are different, Marques (2006) reports that investors react to the component adjustments made by analysts, but not to the additional adjustments made by managers. Her evidence suggests that managers might benefit more from influencing stock valuation through analysts' exclusions than through pro forma realized earnings.

A major component of analysts' total exclusions from street earnings is special items. Special items are the primary reason for the growing difference between street and GAAP earnings (Abarbanell and Lehavy 2007; Bradshaw and Sloan 2002). Because of the uncertainty surrounding the economic events that lead to special items, analysts may be unsure about how transitory the effects are (e.g., do the events affect the firm for 1 year or 3 years?) and the magnitude of these effects. Prior research suggests that investors do not properly account for special items (Dechow and Ge 2006; Burgstahler et al. 2002). Given that special items are, at least

\footnotetext{
9 According to the definition in the Compustat manual, we treat Compustat's operating earnings as a reasonable "recurring earnings" measure and refer to it as "Compustat's version of core earnings" throughout the paper. We are aware of another variable specifically labeled "core earnings" in Compustat after 2002, but do not use it because it does not exclude important nonrecurring items such as restructuring charges.
} 
partly, determined by managers' discretion, managers can anticipate these items and may guide analysts about the permanence and magnitude of these items. As a result, we expect that analysts are more likely to identify and exclude the appropriate amount of special items when managers guide than when they do not guide.

$\mathbf{H}_{1}$ Analysts are more likely to exclude the full amount of special items when managers guide than when they do not guide

Incremental exclusions are analysts' exclusions beyond special items and thus should be comprised exclusively of recurring items. While it is understandable that managers can persuade analysts to exclude special items on the grounds that they are transitory, this rationale does not apply to recurring items. Yet, prior research finds that managers frequently exclude recurring items in calculating pro forma earnings (Black and Christensen 2009). Doyle et al. (2003) and Gu and Chen (2004) imply that analysts may inappropriately exclude some recurring expenses from street earnings. ${ }^{10}$ Given managers' preference for higher street earnings, which can lead investors to value the firm more favorably, managers may use earnings guidance to influence the exclusion of recurring expense/loss items from street earnings and the inclusion of nonrecurring income items in street earnings. Alternatively, managers might influence analysts to exclude some recurring items because they do not believe these items would help investors evaluate the performance of the firm due to measurement issues of these items under the US GAAP. Barth et al. (2009) find evidence consistent with the latter explanation regarding stock-based compensation expense exclusions. Doyle et al. (2003), however, find that incremental exclusions are almost as predictive of future cash flows as the realized street earnings number, suggesting it is inappropriate to exclude these incremental items.

When managers are aggressive in treating certain items as if they are (1) transitory when, in reality, they are recurring and (2) value-irrelevant when, in reality, they are value relevant, analysts may interpret managers' motives for issuing earnings guidance to be opportunistic and not respond to it. On the other hand, managers have superior information about the persistence and value-relevance of the firm's earnings components, and it might be irrational for analysts to completely disregard managers' signals. Moreover, analysts might be under pressure to cooperate with managers for better access to the company's information (Lim 2001), and this incentive may remain even after Regulation Fair Disclosure (Mayew 2008). As a result, analysts may not be inclined to disagree with managers. Prior studies have found evidence suggesting that analysts respond to management earnings guidance even when the guidance is clearly intended to steer analysts in a particular direction (Cotter et al. 2006; Feng and McVay 2010). On balance, we believe that analysts are more likely to respond to earnings guidance than to ignore it. This discussion leads to our second hypothesis:

$\mathbf{H}_{2}$ Analysts' incremental exclusions are higher for firms that issue earnings guidance than for those that do not.

\footnotetext{
${ }^{10} \mathrm{Gu}$ and Chen (2004) note that analysts' exclusions are persistent, suggesting that analysts have excluded items that should have been included (e.g., recurring expenses).
} 
Our hypotheses examine two different aspects of managers' influence on street earnings. Evidence consistent with either $\mathrm{H}_{1}$ or $\mathrm{H}_{2}$ would suggest that managers use earnings guidance to influence street earnings exclusions. $H_{1}$ examines the exclusion of nonrecurring items. Guidance suggesting the exclusion of these items is easier to justify. Analysts would likely exclude special items absent managers' influence as long as analysts view certain items to be transitory for a given firm in a particular business environment. Earnings guidance can help analysts reach this conclusion and determine the amount of special-item exclusions. $\mathrm{H}_{2}$, on the other hand, examines the exclusion of recurring items. In this case, the appropriateness of guidance suggesting the exclusion of recurring items is questionable and the decision about whether to follow the guidance is left to analysts' discretion. Therefore, if our tests indicate that analysts' incremental exclusions are higher for firms that provide earnings guidance, this result would be more compelling evidence of managers' influence in street earnings exclusion decisions than evidence of special-item exclusions.

\section{Research design}

\subsection{Special-item exclusions}

In general, researchers observe only analysts' total exclusions, not the special items excluded by analysts. Given this data limitation, we test $\mathrm{H}_{1}$ by examining the association of special items as identified by Compustat, which we use as an objective measure of special items, with analysts' total exclusions. That is, we regress the amount of analysts' total exclusions on the amount of special items reported by Compustat. If analysts are fully aware of the identity and amount of special items and exclude them accordingly, the coefficient on special items is expected to be 1 (i.e., total exclusions = special items + other exclusions). If analysts experience difficulty in identifying and excluding special items, the association will be less than 1 (i.e., total exclusions $=\alpha^{*}$ special items + other exclusions, where $0<\alpha<1$ ). Thus, the coefficient on special items represents the proportion of the "objective" amount of special items that are excluded by analysts. $\mathrm{H}_{1}$ predicts that, given the objective amount of special items, analysts exclude a greater proportion of these items when managers guide than when they do not guide.

Our empirical model is adapted from Bradshaw and Sloan (2002); Table 4. Bradshaw and Sloan test the ability of special items to explain analysts' total exclusions over time (13 years) by regressing total exclusions on special items, a year trend variable, and the interaction between special items and trend. We drop the trend variable, because our sample period is short and analyzing the trend is not our primary interest, and augment the model by adding variables capturing the volatility of special items in the previous 3 years and glamour stock status.

Figure 2 illustrates the calculation of the exclusion variables used in our analyses. The dependent variable for this test is analysts' total exclusions, TOTAL, measured as the difference between street earnings (STREET) and GAAP earnings (GAAP). STREET is the realized earnings per share (EPS), on a diluted basis, 


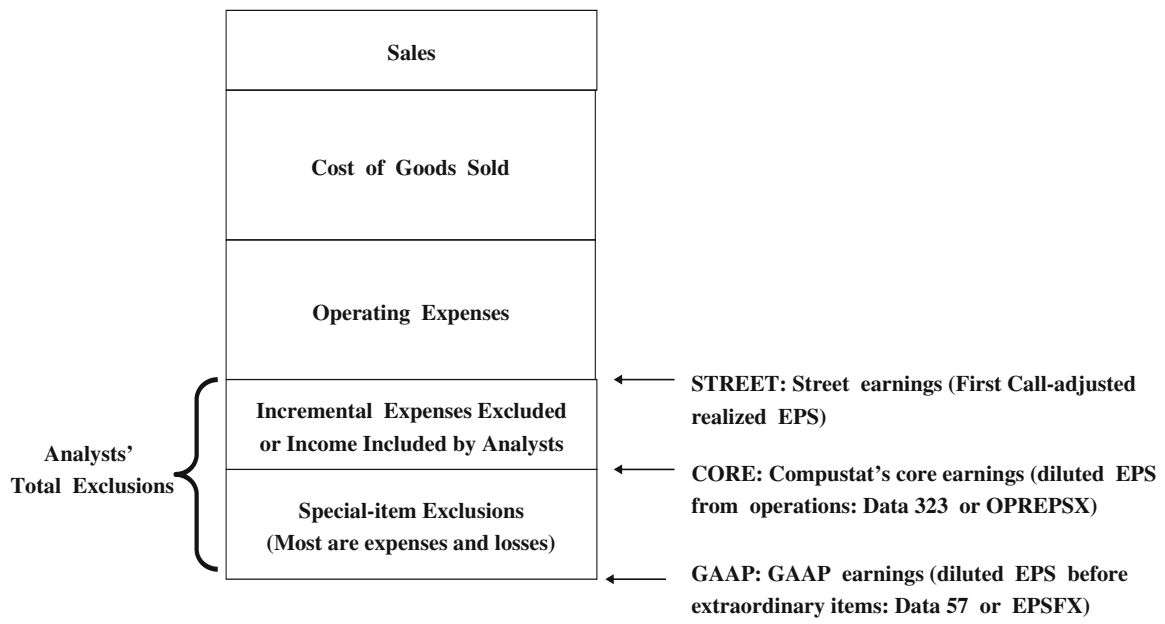

Total Exclusions $=$ Street Earnings - GAAP Earnings

Incremental Exclusions $=$ Street Earnings - Compustat Core Earnings

Fig. 2 Earnings and earnings components

recorded by First Call after it excludes the earnings components that the majority of analysts did not forecast during the fiscal period. GAAP is the diluted EPS before extraordinary items and discontinued operations, obtained from Compustat. For cross-sectional comparisons, all EPS variables are scaled by the beginning-of-year stock price.

Our explanatory variable is the interaction between the amount of special items (SPECIAL) and the issuance of earnings guidance (GUIDE). For proper interpretation of this interaction term, we include the main effects of SPECIAL and GUIDE. We measure SPECIAL as the difference between Compustat's version of core earnings (CORE) and GAAP. CORE is defined in Compustat as the "diluted EPS from operations," calculated as GAAP earnings after special items are removed (e.g., a loss from asset sale is added back) by Compustat. This number is after tax and has already been converted to a diluted EPS. ${ }^{11}$ It appears that Compustat exercises care in computing CORE. Frankel (2009) notes:

Compustat is not "mechanical" in its reliance on categories. For example, if the company sets aside litigation reserves for three consecutive years, they will no longer be classified as nonrecurring. However, the guide notes that if the annual report uses words indicating an item is nonrecurring (for example, "restructuring," "nonrecurring," or "special") Compustat will take management at its word.

\footnotetext{
${ }^{11}$ Compustat also records a data item for special items in aggregate dollar amount. Bradshaw and Sloan (2002) use this variable in their analyses. We do not use this alternative measure because it is a pre-tax measure and it is not reported on a diluted EPS basis. This measurement difference is relevant to comparisons of coefficients between the two studies.
} 
The main effect of SPECIAL captures the association between total exclusions and the "objective" amount of special items for firms that do not guide. We expect the coefficient on SPECIAL to be positive and less than 1 .

GUIDE is coded as 1 if a firm issues at least one earnings forecast for the forthcoming year during the fiscal year and 0 otherwise, according to First Call's Company Issued Guidelines (CIG) database. We exclude forecasts issued after the fiscal year end because they are either preannouncements or warnings and are unlikely to influence the majority of analysts' exclusion decisions (which have already been made by that time). We do not include forecasts issued before the fiscal year begins because analysts' attention is arguably still on the previous year's earnings. ${ }^{12}$ We expect GUIDE to have a positive coefficient because $\mathrm{H}_{1}$ and $\mathrm{H}_{2}$ predict that both components of total exclusions (that is, special-item exclusions and incremental exclusions) are higher when firms guide than when they do not guide, all else being equal. The association between total exclusions and the "objective" amount of special items for firms that guide is captured by the sum of the coefficients on SPECIAL and SPECIAL*GUIDE. $\mathrm{H}_{1}$ predicts a stronger association for guiding firms than for non-guiding firms; therefore, we predict that the coefficient on SPECIAL*GUIDE will be positive.

We control for special item volatility. The more volatile a firm's special items have been in the past, the more uncertain the environment in which it operates, and therefore analysts are likely to make exclusions of greater magnitude. We measure this volatility as the average absolute change in special items in the previous 3 years, VSPECIAL, and expect a positive coefficient.

In light of Baik et al.'s (2009) evidence, we control for glamour stock status. Glamour stocks are expected to have high stock turnover, high $\mathrm{P} / \mathrm{E}$ ratios, positive stock momentum, and high sales growth. TURNOVER is the average monthly trading volume in the previous year, scaled by the number of outstanding shares. To avoid a small scalar problem, we calculate $\mathrm{E} / \mathrm{P}$ ratio rather than $\mathrm{P} / \mathrm{E}$ ratio. $E / P$ is the inverse of the trailing $\mathrm{P} / \mathrm{E}$ ratio, where $\mathrm{P}$ is the price at the beginning of the fiscal year and $\mathrm{E}$ is the operating EPS number from Compustat for the previous year. ${ }^{13} \mathrm{We}$ expect a negative coefficient on E/P. MOMENTUM is the buy-and-hold monthly return in the previous year minus the contemporaneous buy-and-hold monthly

\footnotetext{
12 Chuck et al. (2009) and Lansford et al. (2010, appendix C) document the incompleteness of the CIG database even after Reg. FD. This problem is unlikely to have a material impact on our measurement of GUIDE because guiding firms provide an average (median) number of 3.6 (4) forecasts during the fiscal year. It is unlikely that the CIG omits all these forecasts for a firm year.

13 Similar to Baik et al. (2009), our sample includes a small percentage of negative E/P ratio firms. When firms have respectable stock prices despite reporting losses, they are more glamorous than those that have the same stock prices but report accounting profits and should be included in the test. On the other hand, including loss firms creates two problems. First, some loss firms are depressed instead of being glamorous. Second, among loss firms, the more glamorous firms have less negative E/P ratios. Therefore, we expect the coefficient on $\mathrm{E} / \mathrm{P}$ to be positive for the subsample of loss firms, even though it is negative for the full sample. In a robustness test, instead of using $E / P$, we use a variable that takes the value of positive $\mathrm{E} / \mathrm{P}$ ratios and is coded as 0 if the ratio is negative and a second variable that takes the value of negative $\mathrm{E} / \mathrm{P}$ ratios and is coded as 0 if the ratio is positive. Our results remain unchanged with this specification. We thank an anonymous reviewer for this insight.
} 
return of the value-weighted market index. $\triangle S A L E$ is the sales growth in the previous year. Equation 1 summarizes our model for testing $\mathrm{H}_{1}$.

$$
\begin{aligned}
\text { TOTAL }= & a_{0}+a_{1} \text { GUIDE } \times \text { SPECIAL }+a_{2} \text { GUIDE }+a_{3} \text { SPECIAL }+a_{4} \text { VSPECIAL } \\
& +a_{5} \text { TURNOVER }+a_{6} E / P+a_{7} \text { MOMENTUM }+a_{8} \Delta S A L E+e
\end{aligned}
$$

\subsection{Incremental exclusions}

We test $\mathrm{H}_{2}$ by modifying Eq. 1 to use incremental exclusions, INCREMENT, as the dependent variable. INCREMENT is measured as TOTAL minus SPECIAL (that is, TOTAL $=$ SPECIAL + INCREMENT), or equivalently as the difference between STREET and CORE. We drop SPECIAL and its interaction term with GUIDE from the model because SPECIAL is already removed from TOTAL in calculating the new dependent variable. Equation 2 summarizes the empirical model to test $\mathrm{H}_{2}$. We expect the coefficient on GUIDE to be positive.

$$
\begin{aligned}
\text { INCREMENT }= & b_{0}+b_{1} \text { GUIDE }+b_{2} \text { VSPECIAL }+b_{3} \text { TURNOVER }+b_{4} E / P \\
& +b_{5} \text { MOMENTUM }+b_{6} \Delta S A L E+e
\end{aligned}
$$

\section{Sample}

Our sample period is 2003 through 2007 after Regulation Fair Disclosure (Reg. FD) took effect, allowing 1 year of time for us to collect earnings guidance for year $\mathrm{t}-1$ since we later partition the sample by firms' previous year guidance practices. ${ }^{14}$ Prior to Reg. FD, managers could communicate privately with selected analysts (Ajinkya and Gift 1984; Wang 2007) and therefore did not have to rely on public earnings guidance to influence analysts' earnings estimates. We expect public earnings guidance to be particularly relevant as a means of influencing the composition of analysts' earnings forecasts after the passage of Reg. FD.

We start with First Call's "actuals" data file and require the sample firm-years to have fiscal-year-end date and the earnings announcement date for both the current year and the previous year. We collect the financial statement data from Compustat's Xpressfeed annual data file, the stock returns data from CRSP, the earnings guidance data from CIG, and the institutional ownership data from Thomson Financial. All earnings data are diluted EPS measures scaled by the stock price at the beginning of the fiscal year. ${ }^{15} \mathrm{We}$ adjust earnings and price for stock

\footnotetext{
${ }^{14}$ We avoid 2001 because there appears to be a chilling effect right after the implementation of Reg. FD. For example, Wang (2007) finds that half of the firms that previously provided guidance privately decided not to provide any disclosure after Reg. FD and that the information environment of these firms deteriorated subsequently.

15 We elect to use annual data in our analyses because in recent years, managers' decisions to provide quarterly earnings guidance have been influenced by the mounting criticism of quarterly earnings guidance around 2006 (Houston et al. 2010). According to the NIRI annual surveys, the percentage of its member firms providing quarterly earnings guidance was $61 \%$ at the beginning of 2005, but dropped to $52 \%$ at about the same time in 2006, 14\% in 2007, and 30\% in 2008 (National Investors Relations
} 
splits and drop the observations with a scalar less than 1 to avoid outliers. After these requirements, our sample has 15,209 firm-year observations.

Panel A of Table 1 summarizes the observations by year in the sample period and provides the means of major variables. The frequency of earnings guidance is decreasing over time, consistent with the annual surveys of the National Investors Relations Institute (NIRI). The amount of special items is slightly decreasing over time, consistent with Heflin and Hsu (2008). Our main analyses are robust to controlling for the time trend.

Panel B presents the summary statistics for our test variables (except the indicator variable $G U I D E$ ) after positively signed variables are winsorized at $99 \%$ and others at 1 and $99 \%$. As expected and consistent with prior research, street earnings are higher than Compustat's core earnings, and Compustat's core earnings are higher than GAAP earnings. In our sample, $35.6 \%$ of the firms provide annual earnings guidance and $61.3 \%$ of the sample have non-zero special items (untabulated).

Panel C provides Spearman correlations of the test variables. The amount of analysts' total exclusions is positively correlated with GUIDE and SPECIAL, consistent with our expectations. The amount of analysts' incremental exclusions is not significantly correlated with GUIDE and is correlated with stock turnover, E/P, and sales growth in the predicted directions. Both total exclusions and incremental exclusions are positively correlated with the volatility of special items, suggesting that analysts tend to make larger expense/loss exclusions for firms operating in increased uncertainty. ${ }^{16}$

\section{Main test results}

\subsection{Evidence of special-item exclusions}

Table 2 presents our multivariate analyses for the effect of management earnings guidance on analysts' special-item exclusions. Column 1 indicates that in the full sample, analysts' total exclusions are significantly higher for firms that guide than for those without guidance (coefficient $=0.003, \mathrm{t}=4.50$ ), consistent with our expectation. SPECIAL is significantly positively associated with TOTAL with a coefficient of 0.817 , slightly lower than the theoretical coefficient of 1 when special items are fully excluded by analysts. Column 2 adds the interaction term, but its coefficient is not significantly different from zero, suggesting that the extent to which analysts exclude special items does not vary between guiding and nonguiding firms.

\footnotetext{
Footnote 15 continued

Institute (NIRI) 2006, 2007, 2008). Moreover, more accounting adjustments are made in the fourth fiscal quarter than in any other quarters, resulting in seasonality in the reporting of special items (Bradshaw and Sloan 2002). However, our inferences using quarterly data are largely similar to those using annual data.

${ }^{16}$ GUIDE is negatively correlated with VSPECIAL, consistent with Waymire's (1985) evidence that managers are less likely to issue guidance as the uncertainty of their operations increases.
} 
Table 1 Descriptive statistics

\begin{tabular}{|c|c|c|c|c|c|c|c|c|}
\hline Year & Obs. & GUIDE & STREET & CORE & GAAP & TOTAL & INCREMENT & SPECIAL \\
\hline \multicolumn{9}{|c|}{ Panel A: Sample observations by year along with mean statistics } \\
\hline 2003 & 2,853 & $37.3 \%$ & 0.022 & 0.016 & 0.000 & 0.021 & 0.006 & 0.015 \\
\hline 2004 & 2,937 & $38.1 \%$ & 0.033 & 0.029 & 0.022 & 0.010 & 0.002 & 0.008 \\
\hline 2005 & 3,101 & $34.7 \%$ & 0.028 & 0.027 & 0.019 & 0.008 & 0.002 & 0.007 \\
\hline 2006 & 3,142 & $35.1 \%$ & 0.029 & 0.026 & 0.020 & 0.008 & 0.003 & 0.006 \\
\hline 2007 & 3,176 & $33.3 \%$ & 0.017 & 0.013 & 0.005 & 0.010 & 0.003 & 0.007 \\
\hline \multicolumn{2}{|c|}{ Variable } & \multicolumn{2}{|r|}{ Obs. } & Mean & \multicolumn{2}{|r|}{$\mathrm{P} 25$} & Median & P75 \\
\hline \multicolumn{9}{|c|}{ Panel B: Summary statistics } \\
\hline \multicolumn{2}{|c|}{ STREET } & \multicolumn{2}{|r|}{15,209} & 0.026 & \multicolumn{2}{|r|}{0.018} & 0.050 & 0.071 \\
\hline \multicolumn{2}{|c|}{ CORE } & \multicolumn{2}{|r|}{15,206} & 0.022 & \multicolumn{2}{|r|}{0.012} & 0.048 & 0.070 \\
\hline \multicolumn{2}{|c|}{ GAAP } & \multicolumn{2}{|r|}{15,206} & 0.013 & \multicolumn{2}{|r|}{0.005} & 0.045 & 0.069 \\
\hline \multicolumn{2}{|c|}{ TOTAL } & \multicolumn{2}{|r|}{15,206} & 0.011 & \multicolumn{2}{|r|}{0} & 0 & 0.006 \\
\hline \multicolumn{2}{|c|}{ INCREMENT } & \multicolumn{2}{|r|}{15,206} & 0.003 & \multicolumn{2}{|r|}{-0.001} & 0 & 0.003 \\
\hline \multicolumn{2}{|c|}{ SPECIAL } & \multicolumn{2}{|r|}{15,206} & 0.009 & \multicolumn{2}{|r|}{0} & 0 & 0.005 \\
\hline \multicolumn{2}{|c|}{ VSPECIAL } & \multicolumn{2}{|r|}{15,209} & 0.037 & \multicolumn{2}{|r|}{0.001} & 0.005 & 0.021 \\
\hline \multicolumn{2}{|c|}{ TURNOVER } & & 14,950 & 0.158 & & 0.064 & 0.114 & 0.200 \\
\hline $\mathrm{E} / \mathrm{P}$ & & & 15,206 & 0.022 & & 0.012 & 0.048 & 0.070 \\
\hline MOM & TUM & & 14,861 & 0.144 & & -0.169 & 0.041 & 0.303 \\
\hline$\Delta \mathrm{SAL}$ & & & 14,987 & 0.196 & & 0.011 & 0.110 & 0.258 \\
\hline & & TAL & INCREMENT & GUIDE & SPECIAL & VSPECIAL & TURNOVER E/P & MOM. \\
\hline
\end{tabular}

Panel C: Spearman correlations

\begin{tabular}{|c|c|c|c|c|c|c|c|}
\hline INCREMENT & 0.560 & & & & & & \\
\hline GUIDE & 0.030 & 0.013 & & & & & \\
\hline SPECIAL & 0.517 & -0.216 & 0.002 & & & & \\
\hline VSPECIAL & 0.189 & 0.032 & -0.049 & 0.278 & & & \\
\hline TURNOVER & 0.113 & 0.080 & 0.113 & 0.088 & 0.135 & & \\
\hline $\mathrm{E} / \mathrm{P}$ & -0.222 & -0.177 & 0.194 & -0.155 & -0.207 & -0.163 & \\
\hline MOMENTUM & -0.085 & -0.010 & 0.086 & -0.123 & -0.161 & -0.042 & 0.209 \\
\hline$\triangle$ SALE & -0.044 & 0.017 & 0.045 & -0.084 & -0.217 & 0.179 & 0.014 \\
\hline
\end{tabular}

All correlations that are statistically significant at the 5\% level are bolded

Variable definitions: GUIDE is 1 if the firm issues at least one earnings forecast for the fiscal year (t) during the fiscal year and 0 otherwise. STREET is realized earnings per share (EPS) for the fiscal year as recorded by First Call after it adjusts earnings components to conform with what the majority of financial analysts forecast. It is scaled by the splitadjusted stock price at the beginning of the fiscal year. CORE is diluted EPS from operations as recorded by Compustat. It does not include special items, extraordinary items, or items related to discontinued operations. It is scaled by the split-adjusted stock price at the beginning of the fiscal year. GAAP is diluted EPS before extraordinary items and discontinued operations. It is scaled by the split-adjusted stock price at the beginning of the fiscal year. TOTAL is defined as STREET-GAAP and is the total exclusions by analysts from street earnings. INCREMENT is defined as STREETCORE and is the incremental exclusions by analysts from street earnings. SPECIAL is CORE-GAAP, where special items are as identified by Compustat. VSPECIAL is the average absolute change in SPECIAL in the previous 3 years. It measures the volatility of special items. TURNOVER is the average monthly trading volume in the previous fiscal year scaled by the number of outstanding shares. $E / P$ is the inverse of the trailing $\mathrm{P} / \mathrm{E}$ ratio, where $\mathrm{P}$ is the price at the beginning of the fiscal year and $\mathrm{E}$ is the core EPS for the previous year. MOMENTUM is the buy-and-hold monthly returns in the previous fiscal year minus the contemporaneous buy-and-hold monthly returns of the value-weighted market index, $\triangle S A L E$ is the percentage sales growth in the previous fiscal year

STREET, CORE, GAAP, TOTAL, INCREMENT, SPECIAL, E/P, MOMENTUM, and ASALE are winsorized at 1 and 99\% each year. VSPECIAL and TURNOVER are winsorized at $99 \%$ each year 
Table 2 Earnings guidance and analysts' special-item exclusions

\begin{tabular}{|c|c|c|c|c|}
\hline & \multicolumn{4}{|c|}{ Dependent variable $=$ Total exclusions $($ TOTAL $)$} \\
\hline & & & \multicolumn{2}{|c|}{ Reported special items in prior year? } \\
\hline & & & No & Yes \\
\hline Intercept & $\begin{array}{l}0.004 * * * \\
(5.35)\end{array}$ & $\begin{array}{l}0.005^{* * * *} \\
(5.97)\end{array}$ & $\begin{array}{l}0.005^{* * *} \\
(5.07)\end{array}$ & $\begin{array}{l}0.004 * * * \\
(4.10)\end{array}$ \\
\hline GUIDE $\times$ SPECIAL & & $\begin{array}{l}0.110 \\
(1.62)\end{array}$ & $\begin{array}{l}0.347 * * * \\
(2.78)\end{array}$ & $\begin{array}{l}0.067 \\
(0.87)\end{array}$ \\
\hline GUIDE & $\begin{array}{l}0.003 * * * \\
(4.50)\end{array}$ & $\begin{array}{l}0.002 * * * \\
(3.22)\end{array}$ & $\begin{array}{l}0.002 * * \\
(2.18)\end{array}$ & $\begin{array}{l}0.002 * * * \\
(2.60)\end{array}$ \\
\hline SPECIAL & $\begin{array}{l}0.817 * * * \\
(26.92)\end{array}$ & $\begin{array}{l}0.787 * * * \\
(22.05)\end{array}$ & $\begin{array}{l}0.667 * * * \\
(7.99)\end{array}$ & $\begin{array}{l}0.807 * * * \\
(20.52)\end{array}$ \\
\hline VSPECIAL & $\begin{array}{l}0.020 * * \\
(2.18)\end{array}$ & $\begin{array}{l}0.020 * * \\
(2.16)\end{array}$ & $\begin{array}{l}-0.007 \\
(-0.41)\end{array}$ & $\begin{array}{l}0.019 * * \\
(2.00)\end{array}$ \\
\hline TURNOVER & $\begin{array}{l}0.005 * * \\
(1.96)\end{array}$ & $\begin{array}{l}0.005^{* *} \\
(1.96)\end{array}$ & $\begin{array}{l}-0.000 \\
(-0.11)\end{array}$ & $\begin{array}{l}0.008 * * \\
(2.02)\end{array}$ \\
\hline $\mathrm{E} / \mathrm{P}$ & $\begin{array}{l}-0.084 * * * \\
(-7.61)\end{array}$ & $\begin{array}{l}-0.086^{* * *} \\
(-7.90)\end{array}$ & $\begin{array}{l}-0.079 * * * \\
(-5.01)\end{array}$ & $\begin{array}{l}-0.091 * * * \\
(-6.61)\end{array}$ \\
\hline MOMENTUM & $\begin{array}{l}-0.000 \\
(-0.41)\end{array}$ & $\begin{array}{l}-0.000 \\
(-0.29)\end{array}$ & $\begin{array}{l}0.000 \\
(0.85)\end{array}$ & $\begin{array}{l}-0.000 \\
(-0.60)\end{array}$ \\
\hline$\triangle$ SALE & $\begin{array}{l}-0.001 \\
(-1.43)\end{array}$ & $\begin{array}{l}-0.001 \\
(-1.53)\end{array}$ & $\begin{array}{l}-0.001 \\
(-0.96)\end{array}$ & $\begin{array}{l}-0.001 \\
(-0.77)\end{array}$ \\
\hline Model-fit F statistic & $135.50 * * *$ & $118.97 * * *$ & $28.63^{* * *}$ & $99.38 * * *$ \\
\hline Adjusted $\mathrm{R}^{2}$ & $50.9 \%$ & $51.0 \%$ & $37.2 \%$ & $54.1 \%$ \\
\hline Observations & 14,674 & 14,674 & 5,938 & 8,736 \\
\hline
\end{tabular}

See Table 1 for variable definitions. The estimations are robust to heteroskedasticity and within-firm error correlations. $* * *, * *$, and $*$ denote statistical significance at 1,5 , and $10 \%$ in a two-tailed test, respectively

Prior research has noted that, for some firms, special items are in fact not so "special" because these firms are repeated chargers (Atiase et al. 2005; Fairfield et al. 2009). For repeated chargers, analysts perhaps do not need management guidance to exclude special items from current years' earnings estimates because all they need to do is to look at the previous year's number. We investigate the stickiness of special items in our sample and find that the current year's amount of special items is positively correlated with the previous year's amount with a correlation of 0.251 (untabulated). Using special-item indicator variables, we observe that $74.9 \%$ of the firms with special items in year $t-1$ have special items again in year $t$ (untabulated). Thus, it is important to separate firms with special items in the previous year from those without.

Columns 3 and 4 estimate Eq. 1 separately for the two subsamples. As expected, earnings guidance does not affect the extent to which analysts exclude special items if firms have special items in the previous year (Column 4). The coefficient for SPECIAL is about 0.8 for both guiding and non-guiding firms, significantly lower 
than the theoretical coefficient of 1 . Perhaps if a firm just reported special items in the previous year, analysts are somewhat skeptical and do not respond to managers' guidance. If a firm did not have special items in year $\mathrm{t}-1$, however, the coefficient for SPECIAL is 0.667 for non-guiding firms but about 1 for guiding firms (Column 3). In fact, for the latter we fail to reject that the coefficient for guiding firms is different from 1. The coefficient difference between guiding and non-guiding firms is statistically significant with a t-statistic of 2.78. This result suggests that if the firm did not report special items in the previous year, management earnings guidance helps analysts fully exclude the amount of special items in the current year.

Regarding the control variables, the coefficient on VSPECIAL is positive for the full sample and for the subsample of firms with special items in the previous year, suggesting that total exclusions are higher for firms with more volatile special items (thus more uncertainty). TURNOVER has a positive coefficient for the full sample and the prior-year special-item subsample. $E / P$ has a negative coefficient for the full sample as well as for the subsamples partitioned by the prior-year special item indicator. These results suggest that analysts make more income-increasing exclusions for glamour stocks, consistent with Baik et al. (2009).

\subsection{Evidence of incremental exclusions}

Table 3 presents the results exploring the effect of corporate earnings guidance on analysts' incremental exclusions. For the full sample, the coefficient on GUIDE is 0.003 , statistically significant at the $1 \%$ level. This result indicates that analysts exclude more recurring expenses or include more nonrecurring income items for firms that guide than for those that do not guide, consistent with $\mathrm{H}_{2} \cdot{ }^{17}$ This evidence suggests that managers may influence analysts to exclude less-justifiable items, providing stronger evidence that managers influence analysts' exclusion decisions through earnings guidance.

Prior research notes that earnings guidance practices are sticky: once a firm initiates guidance, it tends to continue the practice (Lang and Lundholm 1996; Anilowski et al. 2007; Lansford et al. 2010). In our sample, the current year's guidance decision is positively correlated with the previous year's decision to guide (correlation coefficient $=0.775$, untabulated). To better understand the influence of management earnings guidance on analysts' exclusion decisions, we partition the sample based on whether the firm issued earnings guidance in the previous year. On the one hand, managers who consistently guide may have developed a good reputation with analysts and thus may be able to influence analysts to a larger degree. On the other hand, managers who have provided guidance in the past might issue guidance to continue the existing practice rather than to influence analysts' exclusion decisions. Columns 2 and 3 indicate that, in both subsamples, analysts' total exclusions are higher for guiding firms than for non-guiding firms. ${ }^{18}$

\footnotetext{
17 Some firms issue multiple forecasts for a fiscal year. In a robustness test, we replace GUIDE with a guidance frequency count for the year. This new variable or alternatively its log transformation is positively associated with incremental exclusions.

18 In some instances, analysts actually exclude less than the total amount Compustat classifies in the special items category, resulting in negative values for INCREMENT. We repeat our Table 3 analyses
} 
Table 3 Earnings guidance and analysts' incremental exclusions

\begin{tabular}{|c|c|c|c|}
\hline & \multicolumn{3}{|c|}{ Dependent variable $=$ Incremental exclusions $(I N C R E M E N T)$} \\
\hline & & \multicolumn{2}{|c|}{ Guided in prior year? } \\
\hline & & No & Yes \\
\hline \multirow[t]{2}{*}{ Intercept } & $0.003 * * *$ & $0.002 * * *$ & $0.006 * * *$ \\
\hline & $(4.26)$ & $(3.01)$ & $(3.66)$ \\
\hline \multirow[t]{2}{*}{ GUIDE } & $0.003 * * *$ & $0.003 * * *$ & $0.004 * * *$ \\
\hline & $(4.82)$ & $(3.22)$ & $(3.29)$ \\
\hline \multirow[t]{2}{*}{ VSPECIAL } & $0.018 * *$ & $0.022 * * *$ & 0.006 \\
\hline & $(2.54)$ & $(2.75)$ & $(0.42)$ \\
\hline \multirow[t]{2}{*}{ TURNOVER } & $0.005^{*}$ & $0.008^{* *}$ & -0.004 \\
\hline & $(1.89)$ & $(2.45)$ & $(-1.05)$ \\
\hline \multirow[t]{2}{*}{$\mathrm{E} / \mathrm{P}$} & $-0.076^{* * *}$ & $-0.062 * * *$ & $-0.140 * * *$ \\
\hline & $(-8.37)$ & $(-6.60)$ & $(-6.22)$ \\
\hline \multirow[t]{2}{*}{ MOMENTUM } & 0.000 & 0.000 & 0.001 \\
\hline & $(0.79)$ & $(-0.02)$ & $(1.08)$ \\
\hline \multirow[t]{2}{*}{$\triangle$ SALE } & -0.001 & -0.001 & $0.004 * *$ \\
\hline & $(-0.88)$ & $(-1.62)$ & $(2.08)$ \\
\hline Model-fit F statistic & $17.26^{* * *}$ & $13.95 * * *$ & $8.16^{* * *}$ \\
\hline Adjusted $\mathrm{R}^{2}$ & $7.1 \%$ & $6.3 \%$ & $13.8 \%$ \\
\hline Observations & 14,674 & 9,433 & 5,241 \\
\hline
\end{tabular}

See Table 1 for variable definitions. The estimations are robust to heteroskedasticity and within-firm error correlations. $* * *, * *$, and * denote statistical significance at 1,5 , and $10 \%$ in a two-tailed test, respectively

We also partition the sample by a firm's frequency of annual earnings guidance in the past 3 years. Firms that guided in at least two out of three previous years are referred to as "dedicated guiders," those that guided in one of the 3 years are called "occasional guiders," and those that did not guide at all in the past 3 years are "past non-guiders." In untabulated tests, we find that the coefficient on GUIDE is positive and statistically significant for all three groups. These results suggest that guidance history does not have a considerable influence on the relation between earnings guidance and analysts' incremental exclusions.

It is important to recognize that both analysts' incremental exclusion decisions and managers' decision to issue guidance might be attributable to the same unobservable and thus omitted factors. If so, our previous test results could be

Footnote 18 continued

after excluding these observations and find that the tenor of our results is unchanged. Similar to the Table 2 results, we find that earnings guidance is significantly positively associated with incremental exclusions only for the firms that did not report special items in the prior year. We conclude that, in general, analysts are more likely to make positive incremental exclusions and less likely to make negative incremental exclusions when managers guide. Although we do not analyze when (or why) analysts sometimes exclude less than the total amount in Compustat's special items variable, our results are unaffected by these instances. However, understanding the instances why analysts make income-decreasing exclusions is an interesting question that we leave for future research. 
biased by such factors. In the appendix, we specifically model managers' guidance decision and calculate the Inverse Mills Ratio (IMR) separately for the guiding and non-guiding firms. Adding this variable to Eq. 2 would control for a potential estimation bias from selection. We find that our previously reported results are robust: with this control, the coefficient on GUIDE is 0.015 with a t statistic of 8.68. The coefficient increases because the selection effect would have biased against our finding the result. That is, IMR has a significantly negative coefficient, meaning that the omitted factors that encourage firms to guide in fact discourage analysts from making incremental exclusions. ${ }^{19}$

In sum, we document a strong association between earnings guidance issuance and analysts' incremental exclusions.

\section{Supplementary analyses}

\subsection{Evidence from hand-collected data}

The analyses in Tables 2 and 3 provide indirect evidence that managers guide analysts to exclude specific line items since our guidance variable, GUIDE, does not distinguish between pro forma and GAAP guidance. To better understand our results, we hand collect and code pro forma earnings guidance for a subsample of firms. Subject to the usual caveats of using a small sample, our objective is to get a preliminary understanding of (1) the prevalence of pro forma earnings guidance and (2) the types of exclusions proposed by firms in the earnings guidance. The answers to these questions might differ between firms that anticipate special items and those that do not. Thus, half of our hand-collected subsample comprises 100 firms, randomly selected from firms that have provided annual earnings guidance according to CIG and have special items for the current year. The other half is a random sample of 100 firms that have provided annual earnings guidance but do not anticipate special items.

Panel A of Table 4 addresses the first question. In this hand-collected sample, $31 \%$ of the firms provide both GAAP and pro forma earnings guidance and $6 \%$ of the firms provide pro forma guidance even in the absence of GAAP guidance. Thus, a total of $37 \%$ of the firms (48\% of special item firms and $25 \%$ of non-special item firms) provide pro forma guidance. Pro forma guidance appears to be widespread and is not attributable solely to the presence of special items.

Panel B addresses the second question. Following Black and Christensen (2009), we classify the types of management exclusions from earnings guidance in four categories: (1) below-the-line items, (2) special items (3), recurring items, and (4) other items (the notes of this panel outline the detailed elements of each category). Of the four categories, we are particularly interested in the "recurring items" category.

\footnotetext{
${ }^{19}$ In an untabulated robustness test, we add firm fixed effects to control for time-invariant factors not included in Eq. 2. The coefficient on GUIDE is still significantly positive.
} 
Table 4 Supplementary analysis: prevalence of pro forma guidance and types of exclusions

\begin{tabular}{|c|c|c|c|c|}
\hline \multicolumn{2}{|l|}{ Guidance type } & Special-item firms & Non-special-item firms & Total \\
\hline \multicolumn{5}{|c|}{ Panel A: GAAP versus pro forma earnings guidance ${ }^{\mathrm{a}}$} \\
\hline \multicolumn{2}{|l|}{ GAAP guidance only ${ }^{\mathrm{b}}$} & 52 & 75 & $127(63.5 \%)$ \\
\hline \multicolumn{2}{|c|}{ Both GAAP \& pro forma guidance ${ }^{c}$} & 37 & 25 & $62(31 \%)$ \\
\hline \multicolumn{2}{|l|}{ Pro forma guidance only } & 11 & 0 & $11(5.5 \%)$ \\
\hline \multicolumn{2}{|l|}{ Total } & 100 & 100 & $200(100 \%)$ \\
\hline Exclusion type & \multicolumn{2}{|c|}{ Special-item firms } & Non-special-item firms & Total \\
\hline \multicolumn{5}{|c|}{ Panel B: Number of exclusions in pro forma earnings guidance ${ }^{d}$} \\
\hline Below-the-line items ${ }^{\mathrm{e}}$ & \multicolumn{2}{|l|}{10} & 4 & $14(8.9 \%)$ \\
\hline Special items ${ }^{\mathrm{f}}$ & \multicolumn{2}{|l|}{27} & 16 & $43(27.4 \%)$ \\
\hline Recurring items ${ }^{\mathrm{g}}$ & \multicolumn{2}{|l|}{44} & 32 & $76(48.4 \%)$ \\
\hline Other items ${ }^{\mathrm{h}}$ & \multicolumn{2}{|l|}{22} & 2 & $24(15.3 \%)$ \\
\hline Total & \multicolumn{2}{|l|}{103} & 54 & $157(100 \%)$ \\
\hline
\end{tabular}

a Panel A reports the type of earnings guidance provided by 200 firms. One hundred of these firms are a random sample of firms providing earnings guidance and reporting special items. The other 100 firms are a random sample of firms providing earnings guidance and reporting no special items

b GAAP guidance means that the firm provided an earnings estimate without any indication of exclusions of certain earnings components other than extraordinary items and discontinued operations

c Pro forma guidance means that the firm indicates that certain items are excluded from the earnings estimate

d Panel B reports the exclusions from the earnings guidance provided by a sample of 73 firms (see Panel A for details). We code exclusions in four categories

e Below-the-line items include (a) extraordinary items, (b) discontinued operations, and (c) cumulative effect of change in accounting principles

f Special items include (a) restructuring charges, (b) gains and losses on sale of assets and other nonoperating gains and losses, (c) merger and acquisition related costs, and (d) early debt retirement costs

$\mathrm{g}$ Recurring items include (a) research and development (R\&D) costs and write-offs of purchased inprocess $\mathrm{R} \& \mathrm{D}$, (b) depreciation and amortization costs (excluding amortization of stock-based compensation), (c) stock-based compensation costs, (d) tax-related items, and (e) interest-related items

${ }^{\mathrm{h}}$ Other items represent nonrecurring items that are not in any of the three preceding categories

We find a total of 103 occurrences of exclusions for special-item firms and 54 for non-special-item firms. In itself, the greater number of exclusions for special-items firms should not be surprising because they are more likely to face transitory items that managers might (justifiably) want to exclude from core earnings. Across the two groups, $48.4 \%$ of the exclusions are recurring items, whereas the percentage of nonrecurring items is $27.4 \% .^{20}$ The data suggest that both special item and nonspecial-item firms seek to persuade analysts to exclude not only transitory items, such as merger-related costs and restructuring costs, but also recurring items. For

\footnotetext{
${ }^{20}$ It might be surprising that in Panel B of Table 4 even for the firms coded as "Non-Special Item Firms", 16 exclusions are special items. This apparent discrepancy arises because our firm categorizations in the columns are based on special items classified by Compustat, whereas the coded special items in the rows are based on categories defined by Black and Christensen (2009). Even though managers may treat an item as a "special item," Compustat does not necessarily agree with managers' claims (Frankel 2009).
} 
example, companies routinely exclude amortization of intangible assets (e.g., Allergan and TNS Inc.) and stock-based compensation expense, (e.g., Cadence) and make revenue adjustments inconsistent with GAAP (e.g., i2 technologies). More importantly, for the four companies cited, we find that analysts' street earnings estimates exclude these expenses as well, lending credence to the argument that managers influence analysts in the composition of street earnings, especially relating to components that are not transitory. ${ }^{21}$

\subsection{Stock compensation expense exclusions}

Our test of $\mathrm{H}_{1}$ examines aggregate nonrecurring item exclusions and our test of $\mathrm{H}_{2}$ examines aggregate recurring item exclusions. While all items in the respective categories are accounted for in each test, these items are heterogeneous. In this section, we provide more direct evidence regarding the role of pro forma earnings guidance by narrowing our focus to analysts' exclusion decisions regarding a specific recurring item-stock compensation expense. This focus allows us to investigate a more specific research question, "Do managers use earnings guidance to influence analysts' decisions to exclude stock compensation expense from street earnings?" The caveat of this analysis is that the result may not generalize to other types of exclusions because of the unique measurement issues of stock compensation expense and its long history of controversy and omission.

We start with a subset of our sample firms that report positive stock compensation expense for fiscal years beginning after June 15, 2005 ("the postSFAS 123R era"). We use the text of the footnote entries from the First Call footnote data file to determine whether analysts excluded stock compensation expense from their forecasts. The data requirements of stock compensation expense and footnote coverage yield a sample of 5,185 observations. The indicator variable, EXCLUDE, is coded 1 if the most recent footnote entry for the firm-year indicates that the analyst consensus forecast excludes stock compensation for the fiscal year and is 0 otherwise. In this sample, $9.5 \%$ of the observations code EXCLUDE as 1, suggesting that analysts include the expense for the vast majority of firms.

Another key variable of interest is the indicator variable for management guidance. We first use GUIDE as defined in previous analyses (i.e., GUIDE $=1$ if managers issue earnings guidance during the year according to CIG). We then refine this variable by reading companies' press releases and creating a new guidance variable, GUIDE*, which is coded 1 if managers issue earnings guidance and specifically exclude stock-based compensation expense in the guidance. Therefore, compared to our main large-sample analysis, this stock expense subsample allows us to conduct not only a more focused test by examining one specific expense item, but it also provides a more direct test by refining the earnings guidance variable. We

\footnotetext{
${ }^{21}$ The inferences are based on AP Financial Wire Oct. 25, 2007 for Cadence, Business Wire Feb. 2, 2006 for i2, Business Wire Jan. 31, 2007 for Allergan, and AP Financial Wire May 7, 2007 for TNS. For example, in the case of i2, the press release states unambiguously "Analysts polled by Thomson Financial expected the company to earn, on average, 30 cents per share on $\$ 70.9$ million in revenue. Analysts estimates were for operating revenue versus total revenue" (AP Financial Wire, "i2 shares surge on 4Q profit," February 2, 2006).
} 
examine whether analysts are more likely to exclude the stock compensation expense when managers provide pro forma guidance that excludes this particular expense item than they would absent such guidance. For this test, we control for glamour statusas we do in the main analyses.

Barth et al. (2009) find that analysts may have information-based reasons to exclude the stock compensation expense. In particular, analysts are more likely to exclude the expense for firms for which the stock compensation expense has a low ability to predict the future profitability of the firm. We control for these factors. Following the procedures of Barth et al., we construct a measure of "predictive ability" and refer to it as "RELEVANCE." For each firm, we estimate Eq. 3:

$$
R O A_{t+1}=c_{0}+c_{1} R O A_{t}+c_{2} C_{O M P}+\varepsilon_{t}
$$

where $R O A$ is the net income before extraordinary items and COMP is the implied stock option expense, both scaled by beginning total assets. We estimate the model using annual data from 1996 through 2005 and we require at least five observations for each estimation. Note that pre-2006 COMP is not a component of ROA. The coefficient on COMP measures the predictive ability of the firm's stock option expense for future earnings. The in-sample fraction ranking of the coefficient is our variable RELEVANCE (the rankings are between 0 and 1 with 1 for the highest value).

In addition to RELEVANCE, we control for the variability of historical implied stock option expense, $V C O M P$, because the more volatile the expense, the more difficult it is to predict and thus the more likely to be excluded by analysts. VCOMP is the standard deviation of COMP during 1996 through 2005. We employ the following logit model for this test:

$$
\begin{aligned}
\operatorname{Prob}(E X C L U D E)= & F\left(d_{0}+d_{1} G U I D E *+d_{2} R E L E V A N C E+d_{3} V C O M P\right. \\
& \left.+d_{4} \text { TURNOVER }+d_{5} E / P+d_{6} M O M E N T U M+d_{7} \Delta S A L E+e\right)
\end{aligned}
$$

Table 5 presents the estimation results. ${ }^{22}$ In the first regression, where GUIDE is as defined as in the main analyses, the significantly positive coefficient on GUIDE indicates that the likelihood that analysts will exclude stock compensation expense is significantly higher for firms that guide than for those that do not guide. ${ }^{23}$ More importantly, when we use our refined guidance variable, GUIDE*, in the second regression, the positive association between analysts' exclusion decisions and managers' guidance strengthens substantially and the model fit improves greatly. Thus, the second regression, which can potentially provide more direct evidence on the association between managers' pro forma exclusion recommendations in

\footnotetext{
22 The results in Table 5 are based on 3,990 observations due to data requirements to construct the control variables.

23 Managers may argue that they encourage analysts to make exclusions when the recurring expenses are not predictive of future performance rather than for opportunistic reasons. Our test controls for this explanation and still finds a positive association between earnings guidance and recurring expense exclusions.
} 
Table 5 Supplementary analysis: stock compensation expense exclusion

\begin{tabular}{|c|c|c|}
\hline \multicolumn{3}{|c|}{ Logit model dependent variable $=\operatorname{Pr}($ EXCLUDE $=1)$} \\
\hline & Model 1 & Model 2 \\
\hline Intercept & $\begin{array}{l}-2.585 * * * \\
(-12.98)\end{array}$ & $\begin{array}{l}-2.636 * * * \\
(-13.34)\end{array}$ \\
\hline GUIDE & $\begin{array}{l}0.516 * * * \\
(3.49)\end{array}$ & \\
\hline GUIDE* & & $\begin{array}{l}1.649 * * * \\
(8.71)\end{array}$ \\
\hline RELEVANCE & $\begin{array}{l}-1.138 * * * \\
(-3.61)\end{array}$ & $\begin{array}{l}-0.954 * * * \\
(-2.94)\end{array}$ \\
\hline VCOMP & $\begin{array}{l}8.211 * * * \\
(7.54)\end{array}$ & $\begin{array}{l}8.078 * * * \\
(7.60)\end{array}$ \\
\hline TURNOVER & $\begin{array}{l}2.723 * * * \\
(7.02)\end{array}$ & $\begin{array}{l}2.602 * * * \\
(6.43)\end{array}$ \\
\hline $\mathrm{E} / \mathrm{P}$ & $\begin{array}{l}-0.734 \\
(-0.94)\end{array}$ & $\begin{array}{l}-0.678 \\
(-0.86)\end{array}$ \\
\hline MOMENTUM & $\begin{array}{l}0.232 * \\
(1.84)\end{array}$ & $\begin{array}{l}0.221 * \\
(1.71)\end{array}$ \\
\hline$\triangle \mathrm{SALE}$ & $\begin{array}{l}-0.630 * * * \\
(-3.91)\end{array}$ & $\begin{array}{l}-0.641 * * * \\
(-3.96)\end{array}$ \\
\hline Wald $\chi^{2}$ & $176.79 * * *$ & $232.42 * * *$ \\
\hline Pseudo $\mathrm{R}^{2}$ & $10.1 \%$ & $13.0 \%$ \\
\hline Observations & 3,990 & 3,990 \\
\hline
\end{tabular}

The sample includes the firm-years from our original sample that report stock-based compensation expense after June 2005 and are covered in the First Call footnote database. EXCLUDE is 1 if the analyst consensus forecast excludes the stock compensation expense, according to the most recent footnote entry for the fiscal year and 0 otherwise. GUIDE, TURNOVER, E/P, MOMENTUM, and $\triangle S A L E$ are defined in Table 1. $G U I D E^{*}$ is 1 if managers explicitly exclude stock compensation expense in the earnings guidance press release (when more than one release is available for the firm-year, the first release is coded) and 0 otherwise. RELEVANCE is a proxy for the predictive ability of stock compensation expense for future earnings as measured in Barth et al. (2009). The measure is a fraction ranking between 0 and 1 with 1 for the highest predictive ability. VCOMP is the standard deviation of the implied annual stock option expense in 1996 through 2005

earnings guidance and analysts' exclusion decisions, provides evidence consistent with our results in the general setting: managers appear to exercise influence on analysts' street earning exclusion decisions through earnings guidance. ${ }^{24}$

\footnotetext{
${ }^{24}$ While the focus of this study is on managers' influence on the street earnings number issued by forecast tracking services, a growing literature explores the voluntary disclosure of realized pro forma earnings metrics in quarterly earnings press releases (e.g., Bhattacharya et al. 2003; Brown et al. 2010). It is important to note that interim earnings announcements containing manager-disclosed pro forma earnings numbers can also influence analysts' exclusions in forecasting annual earnings since quarterly earnings exclusions will almost certainly be excluded from the annual number as well. We find that our previous results are robust to controlling for quarterly pro forma earnings disclosures. Moreover, if we replace GUIDE with a new guidance measure that is coded 1 if the firm has both a management forecast and an interim pro forma earnings disclosure that excludes recurring items, this new guidance measure is more highly associated with incremental exclusions.
} 


\section{Conclusion}

Street earnings are a version of core earnings based on financial analysts' forecasts and reported by analyst forecast tracking services. The adjustments from GAAP earnings used to calculate street earnings ostensibly reflect analysts' collective views on the components of earnings that should be excluded from GAAP earnings. Both anecdotal evidence and prior research have documented the growing influence of street earnings in the capital markets. In fact, street earnings have supplanted GAAP earnings as the primary earnings number used by investors in valuing the firm (Bradshaw and Sloan 2002; Frankel and Roychowdhury 2005). Yet, we know relatively little about how street earnings are determined. The little that we do know about street earnings suggests that street earnings exclusions are a product of analysts' expertise (Gu and Chen 2004) or the result of analysts' incentives for promoting certain stocks (Baik et al. 2009). In other words, the focus of prior research explaining how the composition of street earnings is determined has been analyst-centric.

We believe that, given the importance of street earnings for valuation purposes, managers have an incentive to influence which earnings components are included in or excluded from street earnings. Managers can influence street earnings during the fiscal period by providing earnings guidance advising which components analysts should include or exclude from their forecasts. In other words, managers could influence analysts' exclusion decisions via earnings guidance. We find that among firms with no special items in the prior year, the extent to which analysts exclude the "objective" amount of special items in the current year is higher for firms that guide than for those that do not guide. More importantly, analysts' incremental exclusions beyond special items are much higher for firms that guide than for those that do not guide. In a handcollected subsample, we observe that pro forma earnings guidance is common and that a substantial percentage of exclusions recommended by managers are recurring expense items, such R\&D costs, depreciation and amortization, and stock-based compensation. Furthermore, we find consistent evidence in a specific setting regarding a particular recurring expense-stock compensation expense exclusion-using handcollected earnings guidance that is explicit about this expense exclusion.

Taken together, our results are consistent with the conjecture that managers use earnings guidance as a tool to influence analysts' street earnings exclusions. Our study extends the street earnings literature by examining managers' role in determining street earnings' composition and extends the expectations management literature by shedding light on managers' influence on the components of earnings expectations rather than the sign or level of earnings surprises.

This research is subject to limitations. First, although we find that managers' guidance is associated with both components of analysts' exclusions, it is possible that managers are simply responding to analysts' demands. We cannot rule out the possibility that managers may be the followers and not the initiators of these exclusions. Within-industry variation in the treatment of the same recurring item by analysts (exclusion for one firm but inclusion for another), however, suggests a role for managerial guidance. Second, although results based on a large sample of firms indicate that analysts' exclusions are positively associated with the issuance of 
management earnings guidance, our evidence is largely indirect: we do not observe the communication between the managers and analysts and we elect to use "earnings guidance" as a proxy for "pro forma guidance" in the main analyses owing to data constraints. However, our supplemental analyses based on handcollected data relating to stock-based compensation expense provide direct evidence to bolster our large-sample results. Third, we document that managers appear to influence analysts' street earnings decisions but are silent about whether such influence assists or biases analysts' estimates and investors' stock valuation. We believe our analyses add to our collective understanding of the communication between managers and analysts regarding street earnings and the limitations of our study offer opportunities for future research.

Acknowledgments We thank Ting Chen, Steve Crawford, Marcus Kirk, Lynn Rees, David Reppenhagen, Larry Walther, Richard Sloan (the editor), Mark Bradshaw (the discussant), two anonymous referees, and participants at the 2010 RAST Conference, the Florida State University Accounting Workshop, the 2009 BYU Accounting Research Symposium, and the AAA 2010 Annual Meeting. We also express thanks to Will Ciconte, Candace Jones, Lan Su, Glen Young, Helen Xu, and Ying Zhou for their valuable research assistance. Jenny Tucker thanks the Luciano Prida, Sr. Term Professorship Foundation for financial support.

\section{Appendix: Managers' decision to issue earnings guidance}

To control for a potential selection bias in our primary test, we model managers' earnings guidance decision following Ajinkya et al. (2005). We drop the outside director variable because of data constraints and augment the model with an indicator variable for special items because, as we argue for Hypothesis 1, managers are more likely to guide when they anticipate special items than when they do not. Our probit model is Eq. 5.

$$
\begin{aligned}
\operatorname{Prob}(G U I D E)= & c_{0}+c_{1} S P I+c_{2} S I Z E+c_{3} A N A L Y S T+c_{4} I O+c_{5} M / B+c_{6} L O S S \\
& +c_{7} D E C L I N E+c_{8} V C O R E+c_{9} B E T A+c_{10} L I T I G+e
\end{aligned}
$$

GUIDE is an indicator variable for earnings guidance issuance as defined in Sect. 3. $S P I$ is 1 for firms that report non-zero special items for the current year and 0 otherwise. SIZE is the natural logarithm of total assets at the beginning of the year, proxying for the importance of transparency for large firms. ANALYST proxies for the demands of earnings guidance by analysts for valuation and is measured by the number of estimates in the last consensus for the prior-year earnings compiled by First Call before the prior-year earnings announcement. $I O$ proxies for the demand of earnings guidance by institutional investors for monitoring and is measured as the percentage ownership by institutions according to the most recent $13 \mathrm{~F}$ reports before the current fiscal year begins, obtained from Thomson Financial. We use the market-to-book ratio at the beginning of the fiscal year, $M / B$, to proxy for managers' incentive to avoid a torpedo effect at the earnings announcement from lack of early communication (Skinner and Sloan 2002). Prior studies have found that poorly performing firms are reluctant to provide earnings guidance (Miller 2002; Houston 
Table 6 Probit estimation results

\begin{tabular}{lll}
\hline & Coefficient & t-statistic \\
\hline Intercept & $-0.966^{* * * *}$ & $(-9.68)$ \\
SPI & $0.153^{* * *}$ & $(5.17)$ \\
SIZE & $0.041^{* * *}$ & $(2.91)$ \\
ANALYST & $0.012^{* * *}$ & $(2.96)$ \\
IO & $0.807^{* * *}$ & $(11.98)$ \\
M/B & $0.010^{* * *}$ & $(2.18)$ \\
LOSS & $-0.643^{* * *}$ & $(-15.42)$ \\
DECLINE & $-0.095^{* * *}$ & $(-3.82)$ \\
VCORE & $-1.055^{* * *}$ & $(-4.31)$ \\
BETA & $-0.187^{* * *}$ & $(-7.35)$ \\
LITIG & $0.217^{* * *}$ & $(4.47)$ \\
Wald $\chi^{2}$ & $764.33^{* * *}$ & \\
Pseudo $\mathrm{R}^{2}$ & $10.5 \%$ & \\
Obs. & 14,137 & \\
\hline
\end{tabular}

$* * *, * *$, and $*$ denote statistical significance at 1,5 , and $10 \%$ in a two-tailed test, respectively

et al. 2010). We use two indicator variables as proxies for poor performance: LOSS is coded 1 if the firm experiences losses in the previous year and 0 otherwise. DECLINE is coded 1 if the firm experiences an earnings decline in the previous year (i.e., the GAAP earnings number in the current year is lower than that in the previous year) and 0 otherwise. We model the uncertainty associated with a firm's operations but do not offer directional predictions because reasonable arguments can be made for either direction. VCORE captures the uncertainty in core earnings that managers face and is measured as the average absolute change in core earnings in the previous 3 years, scaled by the stock price at the beginning of the current year (both earnings and price are adjusted for stock splits). BETA captures general business risk and is estimated in a market model using the daily returns in the previous fiscal year. Finally, we include litigation risk and expect firms with exposure to higher risk to be more likely to issue guidance. LITIG is 1 if the 4-digit SIC code is 2833-2836, 8731-8734, 3570-3577, 7370-7374, 3600-3674, or 5200-5961 and 0 otherwise (Francis et al. 1994).

Table 6 presents the results and the tests of significance. We employ standard errors that are robust to heteroskedasticity and within-firm error correlations. As expected, SPI has a positive coefficient, indicating that firms with special items are more likely to guide than those without special items. The results for the other variables are all consistent with prior research. The model pseudo $\mathrm{R}^{2}$ is reasonable at about $10 \%$.

\section{References}

Abarbanell, J., \& Lehavy, R. (2007). Letting the "tail wag the dog": The debate over GAAP versus street earnings revisited. Contemporary Accounting Research, 24(3), 675-762. 
Ajinkya, B., Bhojraj, S., \& Sengupta, P. (2005). The association between outside directors, institutional investors and the properties of management earnings forecasts. Journal of Accounting Research, 43(3), 343-376.

Ajinkya, B. B., \& Gift, M. J. (1984). Corporate managers' earnings forecasts and symmetrical adjustments of market expectations. Journal of Accounting Research, 22(2), 425-444.

Anilowski, C., Feng, M., \& Skinner, D. J. (2007). Does earnings guidance affect market returns? The nature and information content of aggregate earnings guidance. Journal of Accounting and Economics, 44(1-2), 36-63.

Atiase, R. K., Platt, D. E., \& Tse, S. Y. (2005). Operational restructuring charges and post-restructuring performance. Contemporary Accounting Research, 21(3), 493-522.

Baik, B., Farber, D. B., \& Petroni, K. (2009). Analysts' incentives and street earnings. Journal of Accounting Research, 47(1), 45-69.

Barth, M., Gow, I., \& Taylor, D. (2009). Why do some firms' consensus analyst earnings forecasts exclude stock-based compensation expense? Working Paper, Stanford University.

Bhattacharya, N., Black, E. L., Christensen, T., \& Larson, C. (2003). Assessing the relative informativeness and permanence of pro forma earnings and GAAP operating earnings. Journal of Accounting and Economics, 36, 285-319.

Bhattacharya, N., Black, E. L., Christensen, T. E., \& Mergenthaler, R. D. (2007). Who trades on pro forma earnings information? The Accounting Review, 82(3), 581-619.

Black, E. L., \& Christensen, T. E. (2009). US Managers' Use of 'Pro Forma' Adjustments to Meet Strategic Earnings Targets. Journal of Business Finance \& Accounting, 36(3), 297-326.

Bradshaw, M. T., \& Sloan, R. G. (2002). GAAP versus the street: An empirical assessment of two alternative definitions of earnings. Journal of Accounting Research, 40(1), 41-66.

Brown, N., Christensen, T., Elliott, W., \& Mergenthaler, R. (2010). Do managers use pro forma earnings disclosures to cater to investor sentiment? Working paper, Georgia State University, Brigham Young University, University of Illinois, and University of Iowa.

Brown, L. D., \& Sivakumar, K. (2003). Comparing the value relevance of two operating income measures. Review of Accounting Studies, 8, 561-572.

Burgstahler, D., Jiambalvo, J., \& Shevlin, T. (2002). Do stock prices fully reflect the implications of special items for future earnings? Journal of Accounting Research, 40(3), 585-612.

Choi, Y., Lin, S., Walker, M., \& Young, S. (2007). Disagreement over the persistence of earnings components: Evidence on the properties of management-specific adjustments to GAAP earnings. Review of Accounting Studies, 12(4), 595-622.

Chuck, E., Matsumoto, D. A., \& Miller, G. S. (2009). Assessing methods of identifying management forecasts: CIG vs. researcher collected. Working Paper, University of Washington and University of Michigan.

Cotter, J., Tuna, I., \& Wysocki, P. D. (2006). Expectations management and beatable targets: How do analysts react to explicit guidance? Contemporary Accounting Research, 23(3), 593-624.

Dechow, P. M., \& Ge, W. (2006). The persistence of earnings and cash flows and the role of special items: Implications for the accrual anomaly. Review of Accounting Studies, 11, 253-296.

Doyle, J. T., Lundholm, R. J., \& Soliman, M. T. (2003). The predictive value of expenses excluded from pro forma earnings. Review of Accounting Studies, 8, 145-174.

Elliott, J., \& Hanna, D. (1996). Repeated accounting write-offs and the information content of earnings. Journal of Accounting Research, 34, 135-155.

Fairfield, P. M., Kitching, K. A., \& Tang, V. M. (2009). Are special items informative about future profit margins? Review of Accounting Studies, 14(2-3), 204-236.

Feng, M., \& McVay, S. E. (2010). Analysts' incentives to overweight management guidance when revising their short-term earnings. The Accounting Review, 85(5), 1617-1646.

Francis, J., Hanna, D., \& Vincent, L. (1996). Causes and effects of discretionary asset write-offs. Journal of Accounting Research, 34, 135-155.

Francis, J., Philbrick, D., \& Schipper, K. (1994). Shareholder litigation and corporate disclosures. Journal of Accounting Research, 32(2), 137-164.

Frankel, R. (2009). Discussion of “Are special items informative about future profit margins?" Review of Accounting Studies, 14(2-3), 237-245.

Frankel, R., \& Roychowdhury, S. (2005). Testing the clientele effect: An explanation for non-GAAP earnings adjustments used to compute I/B/E/S earnings. Working Paper (MIT).

Gu, Z., \& Chen, T. (2004). Analysts' treatment of nonrecurring items in street earnings. Journal of Accounting and Economics, 38, 129-170. 
Heflin, F., \& Hsu, C. (2008). The impact of the SEC's regulation of non-GAAP disclosures. Journal of Accounting and Economics, 46, 349-365.

Houston, J., Lev, B., \& Tucker, J. (2010). To guide or not to guide? Causes and consequences of stopping and subsequently resuming earnings guidance. Contemporary Accounting Research, 27(1), 143-185.

Hutton, A. P. (2005). Determinants of managerial earnings guidance prior to Regulation Fair Disclosure and bias in analysts' earnings forecasts. Contemporary Accounting Research, 22(4), 867-914.

Lang, M. H., \& Lundholm, R. J. (1996). Corporate disclosure policy and analyst behavior. The Accounting Review, 71(4), 467-492.

Lansford, B. N., Lev, B., \& Tucker, J. (2010). Causes and consequences of disaggregating earnings guidance. Working Paper.

Lim, T. (2001). Rationality and analysts' forecast bias. Journal of Finance, 56(1), 369-385.

Marques, A. (2006). SEC interventions and the frequency and usefulness of non-GAAP financial measures. Review of Accounting Studies, 11(4), 549-574.

Matsumoto, D. (2002). Management's incentives to avoid negative earnings surprises. The Accounting Review 77(3).

Mayew, W. J. (2008). Evidence of management discrimination among analysts during earnings conference calls. Journal of Accounting Research, 46(3), 627-659.

McVay, S. E. (2006). Earnings management using classification shifting: An examination of core earnings and special items. The Accounting Review, 81, 501-531.

Miller, G. S. (2002). Earnings performance and discretionary disclosure. Journal of Accounting Research, 40(1), 173-204.

National Investors Relations Institute (NIRI). (2006). Earnings guidance practices survey. April 6, 2006.

National Investors Relations Institute (NIRI). (2007). Earnings guidance practices survey. June 4, 2007.

National Investors Relations Institute (NIRI). (2008). NIRI and CFA Institute release results of joint study on guidance practices and preferences. May 28, 2008.

Ramakrishnan, R. T. S., \& Thomas, J. K. (1998). Valuation of permanent, transitory, and price-irrelevant components of reported earnings. Journal of Accounting, Auditing and Finance, 13, 301-336.

Richardson, S., Teoh, S. H., \& Wysocki, P. D. (2004). The walk-down to beatable analyst forecasts: The role of equity issuance and insider trading incentives. Contemporary Accounting Research, 21(4), 885-924.

Skinner, D. J., \& Sloan, R. G. (2002). Earnings surprises, growth expectations, and stock returns or don't let an earnings torpedo sink your portfolio. Review of Accounting Studies, 7(2-3), 289-312.

Wang, I. Y. (2007). Private earnings guidance and its implications for disclosure regulation. The Accounting Review, 82(5), 1299-1332.

Waymire, G. (1985). Earnings volatility and voluntary management forecast disclosure. Journal of Accounting Research, 23(1), 268-295. 